\title{
Chromosome doubling in Cattleya tigrina A. Rich
}

\author{
Duplicação cromossômica em Cattleya tigrina A. Rich \\ T. S. A. Menezes-Sá ${ }^{1 *}$; M. de F. Arrigoni-Blank ${ }^{1}$ A. S. da Costa ${ }^{1}$ J J. de A. \\ Santos-Serejo $^{2}$; A. F. Blank ${ }^{1}$; C. A. Soares ${ }^{1}$; G. M. S. Moura ${ }^{1}$ \\ ${ }^{1}$ Departamento de Engenharia Agronômica,Universidade Federal de Sergipe, 49100-000, São Cristóvão, Sergipe, \\ Brazil. \\ ${ }^{2}$ Embrapa Mandioca e Fruticultura Tropical, 44380-000, Cruz das Almas, Bahia, Brazil. \\ *thayssaynara@yahoo.com.br
}

(Recebido em 02 de setembro de 2019; aceito em 02 de novembro de 2019)

\begin{abstract}
Chromosome doubling induction in orchids may benefit their production for resulting in flowers of higher commercial value, larger size and higher content of substances that intensify the color and fragrance when compared with diploid orchids. This work aimed to induce and confirm artificial polyploidization, using flow cytometry and stomatal analysis. Explants were treated with colchicine at concentrations of 0, 2.5, 7.5, and $12.5 \mathrm{mM}$, for 24 and 48 hours and with oryzalin, at concentrations of $0,10,30$, and $50 \mu \mathrm{M}$, for three and six days. For the flow cytometric analysis, a sample of leaf tissue was removed from each plant, crushed to release the nuclei and stained with propidium iodide. In addition to flow cytometry, the ploidy of the antimitotic treated plants was evaluated by stomata analysis. Young leaves were used where the density, functionality and stomatal index were evaluated. Colchicine provided induction of satisfactory polyploidy in C. tigrina at all concentrations and times of exposure, obtaining a greater number of polyploid individuals in the concentration of $12.5 \mathrm{mM}$ for 48 hours. Oryzalin did not induce chromosome duplication at the tested concentrations.

Keywords: Orchidaceae, polyploidy, flow cytometry.
\end{abstract}

A duplicação cromossômica induzida em orquídeas pode beneficiar sua produção por possuírem tamanho e teor de substâncias que intensificam a cor e a fragrância quando comparadas com orquídeas diplóides. Este trabalho teve como objetivo induzir e confirmar a poliploidização artificial, utilizando para isso a citometria de fluxo e análise estomática. Os explantes foram tratados com colchicina nas concentrações de $0 ; 2,5 ; 7,5$ e 12,5 mM, por 24 e 48 horas e com orizalina, nas concentrações de $0,10,30$ e $50 \mu \mathrm{M}$, por três e seis dias. Para as análises de citometria de fluxo, uma amostra de tecido foliar foi retirada de cada planta, triturada para liberação dos núcleos e corada com iodeto de propídio. Além da citometria de fluxo a ploidia das plantas tratadas com antimitóticos foi avaliada por meio da análise dos estômatos. Para isso utilizou-se folhas jovens onde foram avaliadas a densidade, funcionalidade e índice estomático. A colchicina proporcionou indução de poliploidia satisfatória em $C$. tigrina em todas as concentrações e tempos de exposição, obtendo maior número de indivíduos poliploides na concentração de $12,5 \mathrm{mM}$ em 48 horas. Orizalina não induziu a duplicação cromossômica nas concentrações testadas.

Palavras-chave: Orchidaceae, Poliploidia, Citometria de fluxo.

\section{INTRODUCTION}

Species of the family Orchidaceae are ornamental plants of botanical, economic, food, medicinal, and cosmetic interest [13]. The genus Cattleya Lindley is known as the "queen of orchids" owing to its beauty [32]. For being highly appreciated by the market, some species of this genus are endangered, such as $C$. tigrina [4].

The devastation of the Atlantic Forest, which occurs from the State of Pernambuco to Rio Grande do Sul, and the predatory collection results in the loss of genetic material and interferes with genetic variability of species of that habitat. In this way, the study of chromosome duplication becomes relevant, in order to reduce the focus of native species threatened with extinction, since it can provide an increase in vegetative structures of the species, allowing the development of a new cultivar.

Moreover, polyploidy can increase the genetic base by recovering the fertility of interspecific hybrids, reaching higher reproduction rate in a short period [16, 27, 34]. Polyploid plants may 
occur naturally due to some cytological procedures, such as the production of unreduced gametes [3]. Nevertheless, they can be synthetically generated by the chromosome doubling induction of the somatic cellusing antimitotic agents [20]. Many antimitotic agents bind to the proteins that form the fibers of the spindle (tubulins), preventing their polymerization and suppressing fibers formation, which makes it impossible the chromosomes separation at the anaphase, forming cells with a duplicated chromosomal complement [8].

Colchicine, the most commonly used antimitotic agent to induce chromosome doubling, is an alkaloid extracted from the plant Colchicum autumnale. However, besides being highly toxic to both plants and humans, this substance acts efficiently only on dividing cells. Since the substance does not reach all cells of the treated material, mixoploids may occur [5].

Therefore, colchicine needs to be applied at higher amounts, which is highly toxic. Oryzalin is another antimitotic that has been successfully used for the polyploidization of ornamental plants, despite being little explored in orchids [26]. Polyploids induction with colchicine and oryzalin has been used in several plant species, such as Cattleya intermedia [1, 31], Dendrobium nobile [37, 38], Oncidium flexuosum [35], Dendrobium scabrilingue [30], Dendrobium chrysotoxum [2] and Dendrobium, Cymbidium, Epidendrum, Odontioda, Phalaenopsis [26]. However, no studies have reported the application of these antimitotic agents for in vitro polyploids induction in $C$. tigrina.

The polyploidy level changes several anatomical traits, such as leaf thickness and length, stomata size, flower size and texture, and flowering period [40]. Chromosome doubling can be proven by cytogenetic, flow cytometry, which quantifies the nuclei DNA content $[9,42]$ and by stomatal analysis, which studies the size and density of stomata.

Due to the relevance of $C$. tigrina, this study aimed to analyze the production of polyploid plants, to confirm polyploid or mixoploid plants, and to evaluate investigate the effects of artificial polyploidization through flow cytometry and stomatal analysis.

\section{MATERIAL AND METHODS}

\subsection{In vitro polyploidy induction}

Two hundred and forty in vitro C. tigrina plants, were subject to treatments with colchicine $\left(\mathrm{C}_{22} \mathrm{H}_{25} \mathrm{NO}_{6}\right)$ and oryzalin (3,5-dinitro-N4, N4-dipropylsulfanilamide). Colchicine and oryzalin were tested at concentrations of $0,2.5,7.5$, and $12.5 \mathrm{mM}, 0,10,30$, and $50 \mu \mathrm{M}$, respectively [28]. Inoculation was performed in $125 \mathrm{ml}$ Erlenmeyer flask with $30 \mathrm{ml}$ of MS liquid medium under agitation (60 rpm), for 24 and 48 hours for colchicine and three and six days for oryzalin, using $1000 \mathrm{ml}$ Erlenmeyer flasks with $200 \mathrm{ml}$ of MS liquid medium, with constant air bubbling by domestic aquarium air pumps.

The experiments consisted of a completely randomized design, in a $4 \times 2$ factorial scheme, with four concentrations of an antimitotic agent (colchicine or oryzalin), at two exposure times ( 24 and $48 \mathrm{~h}$ for colchicine and three and six days for oryzalin), with six replications composed of five tubes with one plant each.

After the treatments, plants were subject to a triple wash with distilled water and transferred to the MS medium supplemented with $30 \mathrm{~g} \mathrm{l}^{-1}$ of sucrose and $7 \mathrm{~g} \mathrm{l}^{-1}$ of agar for 90 days. Plants were kept in a growth room, with a photosynthetic photon flux density of $40 \mu \mathrm{mol} \mathrm{m} \mathrm{m}^{-2} \mathrm{~s}^{-1}, 12$-hour photoperiod, at $25 \pm 2{ }^{\circ} \mathrm{C}$.

At the end of the 90 days, the plants induced new shoots, which were individualized and cultivated in MS medium supplemented with $30 \mathrm{~g}^{-1}$ sucrose and $7 \mathrm{~g} \mathrm{l}^{-1}$ agar for 60 days. At the end of the 60 days after the cultivation of the individualized shoots, the ploidy level was evaluated by flow cytometry analysis and stomatal analysis.

\subsection{Flow cytometric analysis of plants treated with antimitotic}

Young leaves of Cattleya tigrina and "Sunki Maravilha" (Citrus sunki Hort ex Tan.) were used to determine the DNA content. Citrus sunki presented 2C $=0.745 \mathrm{pg}$ of DNA and was used as an internal reference standard. Samples the middle part of $C$. tigrina leaves treated with antimitotic 
and of the reference standard were macerated together in 1ml of ice-cold Galbraith buffer (1983) [12] for the release of the nuclei. The nuclei suspension was filtered in a CellTrics ${ }^{\circledR} 30 \mu \mathrm{m}$ (Partec), stained with $25 \mu \mathrm{l}$ of a $1 \mathrm{mg} / 1 \mathrm{ml}$ solution of propidium iodide, and stored in a container with crushed ice, in the darkness for two minutes. Samples were analyzed using the Attune ${ }^{\mathrm{TM}}$ NxT Acoustic Focusing Cytometer, and histograms were obtained with the software Attune cytometer. The fluorescence data were acquired from at least 10,000 nuclei of each sample.

The coefficients of variation were obtained in the analysis software, and the nuclear DNA content (pg) of the plants was estimated using the formula:

$$
\text { Sample 2C }(\mathrm{pg})=\frac{\text { sample G1 peak mean }}{\text { Citrus sunki G1 peak mean }} \times 2 \text { C DNA content }
$$

\section{Anatomical analyses of plants subject to chromosome doubling induction}

Samples were collected from the middle of the first fully expanded leaf of in vitro plants.

Leaf paradermic sections were clarified in sodium hypochlorite (1\% active chlorine) and washed in distilled water. The sections were stained with Astra Blue and Safranin (1:1 v/v) and then mounted on semipermanent slides with glycerinated water [36].

For the analyses of density (number of stomata/area), functionality (polar diameter of the stomata/equatorial diameter of the stomata), and stomatal index [(number of stomata/number of stomata + number of epidermal cells) x100], 30 paradermal sections were used, which were photographed with an optical microscope equipped with a LEICA DM500 camera, and visualized on the computer with the LAS EZ® software.

All measurements were taken by the image analysis software UTHSCSA Image Tool (University of Texas, San Antonio, USA), using calibrations with microscopic rulers, photographed at the same photomicrograph magnification.

Stomatal analysis data were subject to analysis of variance, and the means were compared by the Tukey's test at $5 \%$ probability, using the SISVAR software [10], when necessary.

\section{RESULTS AND DISCUSSION}

In the treatments with colchicine, 1,141 plantlets were obtained from 240, with 557 plants with duplicate chromosomes and 584 plants with non-duplicated chromosomes. In the treatments with oryzalin, 916 plantlets were obtained from 240, but no duplicate plant was observed. C. tigrina presented a mean DNA content of $3.21 \mathrm{pg}$ in diploid plants and $6.69 \mathrm{pg}$ in autotetraploid plants. The survival rate was $100 \%$ for plants subject to treatments with colchicine and oryzalin, regardless of the concentrations or exposure time.

The initial growth of the plants at 45 days, in relation to the diploid control, was slow for plants with duplicated chromosomes. It can be inferred that, due to the endoreduplication process existing in this species, which allows its slow growth, and with a new chromosome duplication, the decrease of growth occurred in relation to the diploid control.

Colchicine at concentrations of 2.5 (128 plants), 7.5 (197 plants), and 12.0 (232 plants) mM induced plants with duplicated chromosomes when applied for 24 and 48 hours, as confirmed by flow cytometry (Table 1; Figure 1) and stomatal analysis (Figure 2).

Considering the results analyzed, the seedlings submitted to treatments with colchicine, regardless of concentrations and time of exposure were duplicated. The 12.0 concentration at 24 and 48 hours showed a higher number of duplicate plants (Table 1).

Plants with duplicated chromosomes presented thick leaves, with a more intense color when compared with those of the diploid plants. This result suggests that thick leaves are related to the increase of the enzymes and cellular pigments, accentuating the color of the leaves. Therefore, this phenomenon can be the primary factor for a more intense color verified in the leaves of the tetraploid plant $[14,21]$. These parameters were also reported in other species, with artificial polyploidization, such as Musa spp. [28], rangpur lime (Citrus limonia) [1], Brassica campestris [18] and citrus [19]. 
Table 1. Flow cytometric analysis of C. tigrina subject to treatment with colchicine.

\begin{tabular}{|c|c|c|c|c|c|}
\hline \multirow[t]{2}{*}{$\begin{array}{l}\text { Colchicine } \\
(\mathrm{mM})\end{array}$} & \multirow[t]{2}{*}{$\begin{array}{c}\text { Total } \\
\text { number of } \\
\text { plants }(n)\end{array}$} & \multicolumn{2}{|c|}{$\begin{array}{c}\text { Plants with duplicated } \\
\text { chromosomes }(\%)\end{array}$} & \multicolumn{2}{|c|}{$\begin{array}{l}\text { Plants with non- } \\
\text { duplicated chromosomes }\end{array}$} \\
\hline & & Number & Average & Number & Average \\
\hline 0 & 89 & $0(0.00 \%)$ & $0.00 \mathrm{a}$ & 89 & $2.96 \mathrm{a}$ \\
\hline 2.5 for $24 \mathrm{~h}$ & 177 & $55(31.07 \%)$ & $1.83 \mathrm{a}$ & 122 & $4.06 \mathrm{a}$ \\
\hline 7.5 for $24 \mathrm{~h}$ & 167 & $97(58.08 \%)$ & $3.23 \mathrm{a}$ & 70 & $2.33 \mathrm{a}$ \\
\hline 12 for $24 \mathrm{~h}$ & 166 & $100(60.24 \%)$ & $3.33 \mathrm{~b}$ & 66 & $2.20 \mathrm{a}$ \\
\hline 0 & 85 & $0(0.00 \%)$ & $0.00 \mathrm{a}$ & 85 & $2.83 \mathrm{a}$ \\
\hline 2.5 for $48 \mathrm{~h}$ & 130 & $73(56.15 \%)$ & $2.43 \mathrm{a}$ & 57 & $1.90 \mathrm{~b}$ \\
\hline 7.5 for $48 \mathrm{~h}$ & 145 & $100(68.96 \%)$ & $3.33 \mathrm{a}$ & 45 & $1.50 \mathrm{~b}$ \\
\hline 12 for $48 \mathrm{~h}$ & 182 & $132(72.52 \%)$ & $4.40 \mathrm{a}$ & 50 & $1.66 \mathrm{~b}$ \\
\hline CV (\%) & & & 27.83 & & 12.37 \\
\hline
\end{tabular}

* Means followed by same letter, between 24 and $48 \mathrm{~h}$, do not differ by Tukey's test $(\mathrm{p} \leq 0.05)$. 

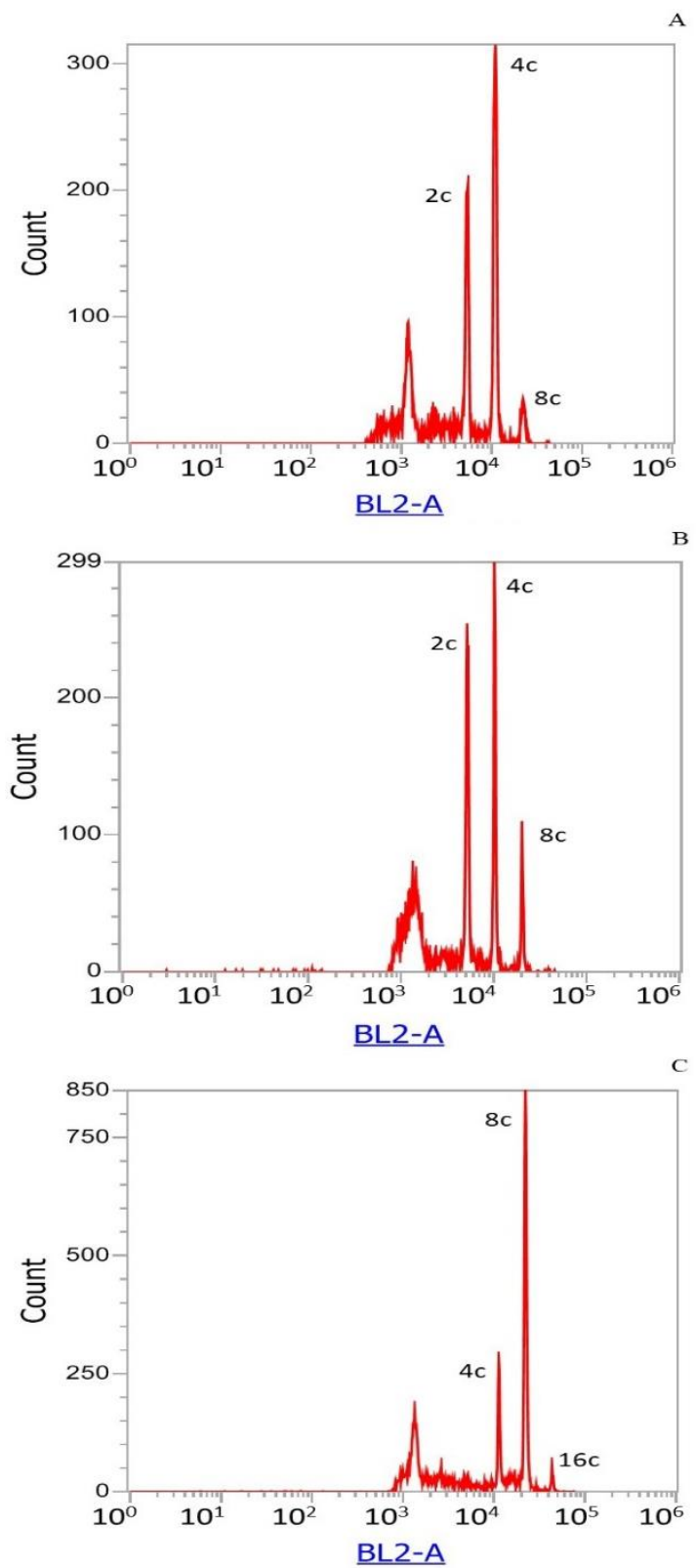

Figure 1. Flow cytometry histograms of Cattleya tigrina plants treated with colchicine using Citrus sunki as an internal reference standard. A) Control; B) Treatment with oryzalin; C) Treatment with $2.5 \mathrm{mM}$ colchicine for 24 hours

Cattleya tigrina presents endopolyploidy, with cells of three different ploidies in the same tissue in their natural environment. Thus, the control plant had more diploid and tetraploid cells (Figure 1A). The chromosome doubling induction resulted in plants with more tetraploid and octoploid cells (Figure 1C).

There was a significant difference between the concentrations and the estimated amount of DNA. All the histograms obtained indicated 3 distinct peaks and in all of them the result was similar. The control seedlings, that is, without passing through antimitotic substances showed lower DNA indexes. Seedlings grown in the other treatments on antimitotic substances had higher DNA contents (Table 2). In all the histograms it was possible to observe that the three peaks showed values that are multiples of each other (Table 2), thus demonstrating that endoreduplication occurred, which leads us to infer that ploidies are $2 \mathrm{C}$ in the first peak, $4 \mathrm{C}$, in the second and $8 \mathrm{C}$ on the third. Figure 1 shows the histograms of the analyzed treatments and in all of them we can observe three peaks of $C$. tigrina and one peak of the internal reference standard (represented by the first peak), which was used to calculate the DNA indexes. 
Table 2. DNA index (ID) of C. tigrina submitted to treatment with colchicine and analyzed on a flow

\begin{tabular}{llll}
\multicolumn{4}{c}{ cytometer. } \\
\hline Colchicine (mM) & ID & ID & ID \\
& Peak 1 & Peak 2 & Peak 3 \\
\hline 0 & $3.23 \mathrm{~b}$ & $6.40 \mathrm{~b}$ & $12.68 \mathrm{~b}$ \\
2,5 for $24 \mathrm{~h}$ & $6.11 \mathrm{a}$ & $12.18 \mathrm{a}$ & $24.32 \mathrm{a}$ \\
7,5 for $24 \mathrm{~h}$ & $6.21 \mathrm{a}$ & $12.34 \mathrm{a}$ & $24.52 \mathrm{a}$ \\
12,5 for $24 \mathrm{~h}$ & $6.32 \mathrm{a}$ & $12.37 \mathrm{a}$ & $24.55 \mathrm{a}$ \\
0 & $3.23 \mathrm{~b}$ & $6.40 \mathrm{~b}$ & $12.68 \mathrm{~b}$ \\
2,5 for $48 \mathrm{~h}$ & $6.20 \mathrm{a}$ & $12.29 \mathrm{a}$ & $24.43 \mathrm{a}$ \\
7,5 for $48 \mathrm{~h}$ & $6.20 \mathrm{a}$ & $12.40 \mathrm{a}$ & $24.44 \mathrm{a}$ \\
12,5 for $48 \mathrm{~h}$ & $6.25 \mathrm{a}$ & $12.46 \mathrm{a}$ & $24.49 \mathrm{a}$ \\
\hline CV $(\%)$ & 8.43 & 7.36 & 7.24 \\
\hline
\end{tabular}

* Means followed by the same letter, in the columns, do not differ by the Tukey test $(\mathrm{p} \leq 0.05)$.

The endoreduplication process was possibly indicated during evolution for the benefit of plants and organ development. According to the diverse situations identified in several species, in relation to the plant, organ or cellular physiology, many functional roles were described to seek to clarify the importance of endoreduplication [7]. The endoreduplication occurs during differentiation of cells that are highly specialized in their morphology, such as succulent leaves of $C$. tigrina that stores large amount of water internally. The survival rate was $100 \%$ for C. tigrina plants subject to oryzalin treatments, regardless of the concentrations and exposure time. Thus, oryzalin did not impair plants survival.

Moreover, oryzalin induces chromosome doubling at concentrations lower than those used for colchicine owing to the high-affinity binding of dinitroanilines to tubulin and the stability of the oryzalin-tubulin complex [11, 28]. In the present study, the concentrations of the antimitotic agent tested appear to have been very low and ineffective for chromosomes doubling (Table 3). Oryzalin did not provide duplicate plants at the times and treatments tested (Figure 1B), therefore, in the future, new studies are needed for this species, testing higher concentrations and varying the immersion times.

Cattleya tigrina responded differently to the antimitotic agents tested since the chromosomal doubling capacity of the substances (colchicine and oryzalin) was different. However, colchicine concentrations favored doubling. Results confirm that chromosome doubling varies according to the type, species, genotype, exposure time, age, and application technique [8, 39]. This fact was also verified in Dendrobium nobile [37, 38], Oncidium flexuosum [35], and Dendrobium scabrilingue [30].

Plant ploidy can be safely determined in the flow cytometric analysis since the DNA content is not influenced by external factors, such as water content in the plant tissue, leaf blade development, and light intensity [28]. Another methodology used to identify chromosome number counts is cytogenetics as seen in Dendranthema nankingense [23] and Lilium leichtlinii [15].

Table 3. Flow cytometric analysis of C. tigrina subject to treatment with oryzalin.

\begin{tabular}{lccc}
\hline Oryzalin $(\boldsymbol{\mu M})$ & $\begin{array}{c}\text { Total number } \\
\text { of plants }\end{array}$ & $\begin{array}{c}\text { Number of plants with } \\
\text { duplicated chromosomes } \\
(\boldsymbol{\%})\end{array}$ & $\begin{array}{c}\text { Number of plants with } \\
\text { non-duplicated } \\
\text { chromosomes }\end{array}$ \\
\hline 0 & 62 & $0(0.00 \%)$ & 62 \\
10 for 3 days & 115 & $0(0.00 \%)$ & 115 \\
30 for 3 days & 161 & $0(0.00 \%)$ & 161 \\
50 for 3 days & 166 & $0(0.00 \%)$ & 166 \\
\hline 0 & 68 & $0(0.00 \%)$ & 68 \\
10 for 6 days & 136 & $0(0.00 \%)$ & 136 \\
30 for 6 days & 102 & $0(0.00 \%)$ & 102 \\
50 for 6 days & 106 & $0(0.00 \%)$ & 106 \\
\hline
\end{tabular}


During the development of some plants the normal cell cycle can be modified by a different cell cycle, in which it does not perform mitosis [7]. This altered cycle called the endoreduplication cycle is based on one or several cycles of DNA synthesis in the absence of mitosis, enabling the process of cell expansion, and collaborating for the growth of plant organs [25]. This event can occur in several cells of the plant, especially those submitted to aging or differentiation [29].

Endopolyploidy in plants has been seen in several different tissues [24]. In higher plants is a common characteristic, being analyzed in tissues and organs of the species [29]. In the family Orchidaceae the occurrence of endopolyploidy in the genus Cattleya was verified, with 40 chromosomes, in the species $C$. trianae, $C$. grandis, $C$. guttata, C. labiata, C. cernua, C. tenius, C. elongata, C. crispata, C. rupestres, C. aclandiae, C. amethystoglossa, C. pfisterii, C. rupestris, C. sincorana, $C$. loddigesii, and $C$. granulosa, resulting in the presence of $2 \mathrm{C}, 4 \mathrm{C}$, and $8 \mathrm{C}$ peaks [33]. It was identified that this species also has this characteristic, confirmed by flow cytometry.

Stomatal analysis is a method that allows the identification of polyploid and diploid plants via counting and comparative verification of stomata, since the length of the stomata increases with the number of chromosomes $[6,28]$. The increase in the ploidy level is directly proportional to the size and number of the stomata. Several authors have reported larger stomata and with a lower density of tetraploid plants on diploid plants in different plant species [40, 41]. This technique is considered one of the indicators to estimate the rate of polyploidy in several species such as Cattleya intermedia [31], Vanda [22], Cymbidium [17], Dendrobium nobile [36] and Dendrobium chrysotoxum [2].

In the present study, the stomatal analysis was efficient to determine the occurrence or not of chromosome doubling, corroborating the results obtained by flow cytometry. Most of the plants classified as having duplicated chromosomes by flow cytometry were also identified in the stomatal analysis. Thus, due to its lower cost, this analysis can be used to pre-select possible polyploids, reducing the number of samples for the flow cytometry analysis.

The function of stomata in plants with duplicated chromosomes (1.25) was significantly higher, and stomatal density $\left(3.30 \mathrm{~mm}^{2}\right)$ was lower when compared with plants with non-duplicated chromosomes (1.09) (Table 4). These data corroborate with the results with studies of other species, such as Dendrobium nobile and Musa spp., which stated that polyploid plants have a lower density of stomata than the control $[28,36]$. The stomata are important because they have the function to perform gas exchanges, however in doubling the stomata do not change the physiology of the plant. In ornamental plants the stomata has no influence on commercial characteristics, while duplication favors the increase of floral structures, with a more rounded conformation and greater content of substances that intensify the color and fragrance, when compared with the diploid orchids.

Table 4. Density, functionality, and stomatal index in leaves of C. tigrina plants without and with duplicated chromosomes, treated with oryzalin.

\begin{tabular}{lccc}
\hline Ploidy level & $\begin{array}{c}\text { Density } \\
\left(\mathbf{m m}^{2}\right)\end{array}$ & $\begin{array}{c}\text { Functionality (polar } \\
\text { diameter/equatorial diameter) }\end{array}$ & $\begin{array}{c}\text { Stomatal } \\
\text { index }\end{array}$ \\
\hline Non-duplicated chromosomes & $7.61 \mathrm{a}$ & $1.09 \mathrm{~b}$ & $6.96 \mathrm{a}$ \\
Duplicated chromosomes & $3.30 \mathrm{~b}$ & $1.25 \mathrm{a}$ & $4.28 \mathrm{~b}$ \\
\hline $\mathrm{CV}(\%)$ & 3.48 & 7.79 & 3.85 \\
\hline
\end{tabular}

* Means followed by the same letter, in the columns, do not differ by the Tukey test $(\mathrm{p} \leq 0.05)$.

The stomatal index in diploid plants (6.96) was higher in relation to plants with duplicated chromosomes. Thus, the increase in the stomatal index (frequency of stomata) in the diploid leaves of $C$. tigrina may be related to the smaller size of the stomata and the smaller size of the epidermal cells.

The non-duplicated plants showed smaller stomata and in major quantity (Figures 2A and 2B), while the duplicated plants had larger stomata and in minor quantity (Figures $2 \mathrm{C}$ and 2D). Flow cytometry confirmed the occurrence of duplication of chromosomes. 


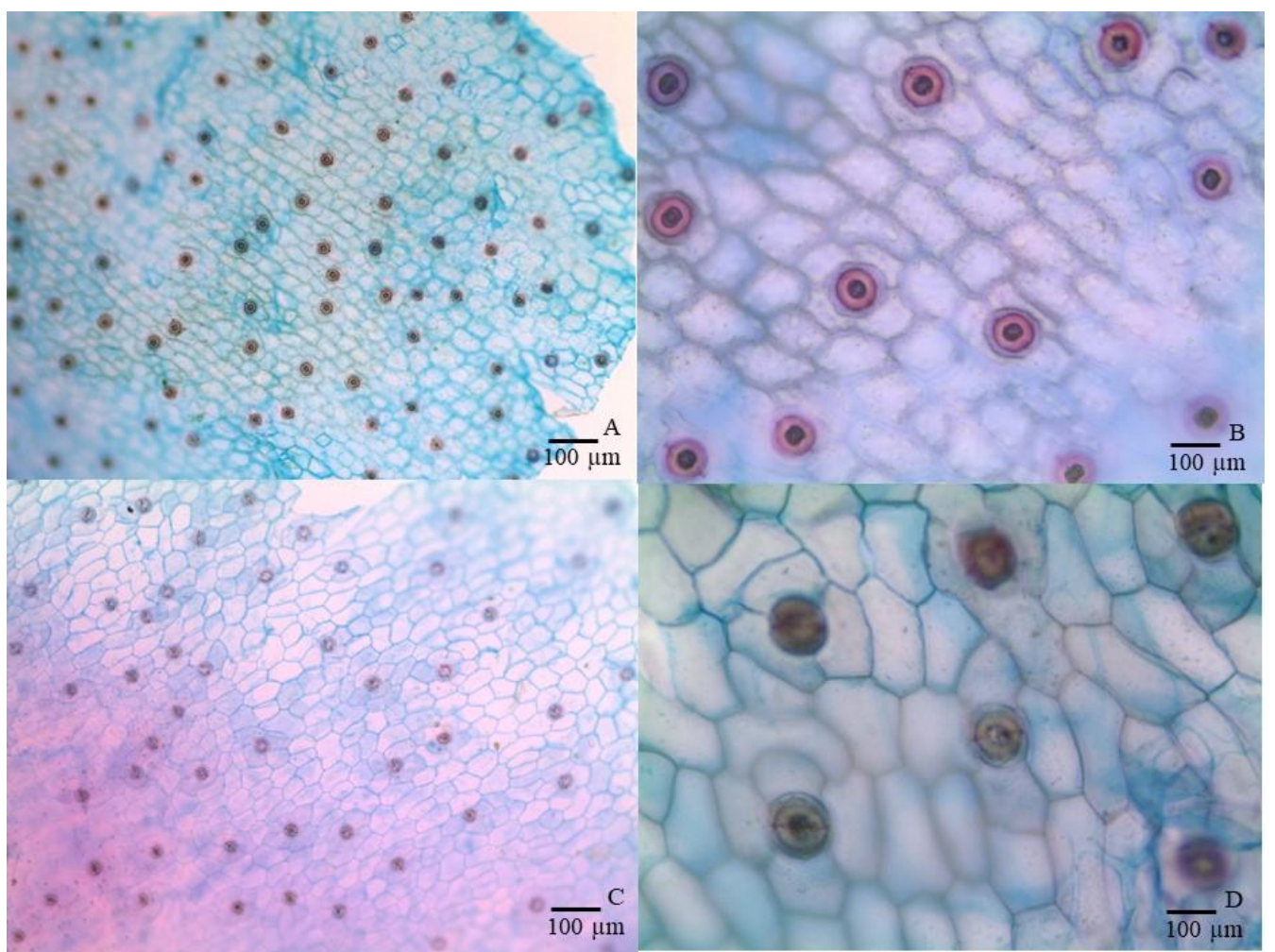

Figure 2. Stomatal analysis of a control plant (A and B) and a plant with duplicated chromosomes $(C$ and D) of Cattleya tigrina. Fonte: Os autores

\section{CONCLUSION}

Colchicine provided induction of satisfactory polyploidy in C. tigrina at all concentrations and times of exposure, obtaining a greater number of polyploid individuals in the concentration of $12.5 \mathrm{mM}$ for 48 hours. Oryzalin did not induce chromosome duplication at the tested concentrations.

\section{ACKNOWLEDGMENTS}

This study was financed in part by the Conselho Nacional de Desenvolvimento Científico e Tecnológico - Brasil (CNPq), the Fundação de Apoio à Pesquisa e a Inovação Tecnológica do Estado de Sergipe (Fapitec/SE) - Brasil, the Coordenação de Aperfeiçoamento de Pessoal de Nível Superior - Brasil (CAPES - Finance Code 001), and the Financiadora de Estudos e Projetos - Brasil (FINEP).

\section{REFERENCES}

1. Allario T, Brumos J, Colmenero-Flores JM, Tadeo F, Froelicher Y, Talon M, Navarro L, Ollitrault P, Morillon R. Large changes in anatomy and physiology between diploid Rangpur lime (Citrus limonia) and its autotetraploid are not associated with large changes in leaf gene expression. J Experim Bot. 2011;62(8):2507-2519, doi:10.1093/jxb/erq467

2. Atichart P, Polyploid Induction by Colchicine Treatments and Plant Regeneration of Dendrobium chrysotoxum. Thai J Agric Sci. 2013;46(1):59-63.

3. Barow M, Jovtchev G. Endopolyploidy in Plants and its Analysis by Flow Cytometry. In: Doležel J, Greilhuber J, Suda J, editors. Flow Cytometry with Plant Cells Wiley. 2007;349-370, doi:10.1002/9783527610921.ch15

4. Brasil. Ministério do Meio Ambiente (MMA). 2014. Portaria nº43, de 17 de dezembro de 2014. Lista oficial das espécies da flora brasileira ameaçadas de extinção. Diário Oficial [da República Federativa do Brasil], Brasília, DF.

5. Carvalho JFR, Carvalho CR, Otoni WC. In vitro induction of polyploidy in annato (Bixa orellana). Plant Cell, Tissue Organ Cult. 2005;80(1):69-75, doi:10.1007/s11240-004-8833-5 
6. Campos JMS, Davide LC, Salgado CC, Santos FC, Costa PN, Silva PS, Alves CCS, Viccini LF, Pereira AV. In vitro induction of hexaploid plants from triploid hybrids of Pennisetum purpureum and Pennisetum glaucum. Plant Breed. 2009;128(1):101-104, doi:10.1111/j.1439-0523.2008.01546.x

7. Chevalier C, Nafati M, Mathieu-Rivet E, Bourdon M, Frangne N, Cheniclet C, Renaudin JP, Gévaudant $\mathrm{F}$, Hernould M. Elucidating the functional role of endoreduplication in tomato fruit development. Ann Bot. 2011;107(1):1159-1169.

8. Dhooghe E, Laere KV, Eeckhaut T, Leus L, Huylenbroeck JV. Mitotic chromosome doubling of plant tissues in vitro. Plant Cell, Tissue Organ Cult. 2011; 104(3):359-373, doi:10.1007/s11240-010-9786-5

9. Dolezel J, Bartos J. Plant DNA flow cytometry and estimation of nuclear genome size. Ann Bot. 2005;95(1):99-110, doi:10.1093/aob/mci005

10. Ferreira DF. Sisvar: a computer statistical analysis system. Ci Agrotec. 2011;35(6):1039-1042, doi:10.1590/S1413-70542011000600001

11. Ganga M, Chezhiyan N. Influence of the antimitotic agents colchicine and oryzalin on in vitro regeneration and chromosome doubling of diploid bananas (Musa spp.). J Hortic Sci Biotechnol. 2002;77(5):572-575, doi:10.1080/14620316.2002.11511540

12. Galbraith DW, Harkins KR, Maddox JM, Ayres JM, Sharma DP, Firoozabady E. Rapid flow cytometric analysis of the cell cycle in intact plant tissue. Science. 1983;220(4601):1049-1051, doi:10.1126/science.220.4601.1049

13. Galdiano-Junior RF, Mantovani C, Pivetta KFL, Lemos EGM. Crescimento in vitro e aclimatização de Cattleya loddigesii Lindley (Orchidaceae) com carvão ativado sob dois espectros luminosos. Ci Rural. 2012;42(5):801-807, doi:10.1590/S0103-84782012005000019.

14. Guerra D, Wittmann MTS, Schwarz SF, Souza PVD, Gonzatto MP, Weiler RL. Comparison between diploid and tetraploid citrus rootstocks: morphological characterization and growth evaluation. Bragantia. 2014;73(1):1-7, doi:10.1590/brag.2014.007

15. Heo JY, Jeong SH, Choi HR, Park SM. Polyploid production in Lilium leichtlinii var. maximowiczii using colchicine. J Anim Plant Sci. 2016;26(4):1111-1116.

16. Ishigaki G, Gondo T, Suenaga K, Akashi R. Induction of tetraploid ruzigrass (Brachiaria ruziziensis) plants by colchicine treatment of in vitro multiple-shoot clumps and seedlings. Grassland Sci. 2009;55(3):164-170, doi:10.1111/j.1744-697X.2009.00153.x

17. Kim MS, Kim JY. Chromosome doubling of a Cymbidium hybrid with colchicine treatment in meristem culture. Proceedings of NIOC. 2003;37-40.

18. Kumar G, Dwivedi K. Induced polyploidization in Brassica campestris L. (Brassicaceae). Cytol Genet. 2014;48(2):103-110, doi:10.3103/S0095452714020066

19. Latado RR, Cristofani-Yaly M, Carvalho CR, Machado MA. Plantas autotetraploides de citros sob tratamento in vitro com colchicina. Pesq Agropec Bras. 2007;42(10):1429-1435, doi:10.1590/S0100204X2007001000009.

20. Lee GJ, Chung SJ, Park IS, Lee JS, Kim JB, Kim DS, Kang SY. Variation in the phenotypic features and transcripts of color mutants of chrysanthemum (Dendranthema grandiflorum) derived from gamma ray mutagenesis. J Plant Biol. 2008;51(6):418-423, 2008, doi:10.1007\%2FBF03036063

21. Leech RM, Leese BM, Jellings AJ. Variation in cellular ribulose-1, 5-bisphospahte-carboxylase content in leaves of triticum genotypes at tree levels of ploidy. Planta. 1985;166(2):259-263, doi:10.1007/BF00397357

22. Lim WL, Loh CS. Endopolyploidy in Vanda Miss Joaquim (Orchidaceae). New Phytologist. 2003;159(1): 279-287, doi:10.1046/j.0028-646x.2003.00797.x

23. Liu S, Chen S, Chen Y, Guan Z, Yin D, Chen F. In vitro induced tetraploid of Dendranthema nankingense (Nakai) Tzvel. shows an improved level of abiotic stress tolerance. Scia Horticult. 2011;127(3):411-419, doi:10.1016/j.scienta.2010.10.012

24. Loureiro J, Rodriguez E, Dolezel J, Santos C. Comparison of four nuclear isolation buffers for plant DNA flowcytometry. Ann Bot. 2017;98(3):679-89, doi:10.1093/aob/mcl141

25. Lukaszewska E, Sliwinska E. Most organs of sugar-beet (Beta vulgaris L.) plants at the vegetative and reproductive stages of development are polysomatic. Sexual Plant Reprod. 2007;20(1):99-107.

26. Miguel TP, Leonhardt KW. In vitro polyploid induction of orchids using oryzalin. Sci Horticult. 2011;130(1):314-319, doi:10.1016/j.scienta.2011.07.002

27. Pereira RC, Ferreira MTM, Davide LC, Pasqual M, Mittelmann A, Techio VH. Chromosome duplication in Lolium multiflorum Lam. Crop Breed Appl Biotechnol. 2014;14(3):251-255, doi:10.1590/1984-70332014v14n4n39

28. Pio LAS, Pasqual M, Silva SO, Rocha HS, Magalhaes HM, Santos-Serejo JA. Inducing and identifying artificially-induced polyploidy in bananas. Afr J Biotechnol. 2014;13(37):3748-3758, doi:10.5897/AJB2014.14009 
29. Sabelli PA, Larkins BA. The contribution of cell cycle regulation to endosperm development. Sexual Plant Reprod. 2009;22(1):207-219.

30. Sarathum S, Hegele M, Tantiviwat S, Nanakorn M. Effect of concentration and duration of colchicine treatment on polyploidy induction in Dendrobium scabrilingue L. European J Horticult Sci. 2010;75(3):123-127.

31. Silva PAKXM, Callegari-Jacques S, Bodanese-Zanettini MH. Induction and identification of polyploids in Cattleya intermedia Lindl (Orchidaceae) by in vitro techniques. Ci Rural. 2000;30(1):105-111, doi:10.1590/S0103-84782000000100017.

32. Soares JDR, Pasqual M, Rodrigues FA, Villa F, Araujo AG. Fontes de silício na micropropagação de orquídea do grupo Cattleya. Acta Sci Agron. 2011;33(3):503-507, doi:10.4025/actasciagron.v33i3.6281

33. Souza BCQ, Souza ACM, Almeida EM, Felix LP. Orchidaceae - IAPT/IOPB chromosome data 26. TAXON. 2017;66(6):1487-1499, doi:10.12705/666.30

34. Souza-Kaneshima AM, Risso-Pascotto C, Pagliarini MS, Valle CB. Meiotic behaviour in the first interspecific hybrids between Brachiaria brizantha and Brachiaria decumbens. Plant Breed. 2010;129(2):186-191, doi:10.1111/j.1439-0523.2009.01674.x.

35. Unemoto LK, Faria RT, Destro D, Barbosa CM, Lone AB. Sobrevivência e diferenciação de protocormos de Oncidium flexuosum submetidos a tratamento com ácido peracético e colchicina. Acta Sci Agron. 2009;31(3):503-508, http://dx.doi.org/10.4025/actasciagron.v31i3.697

36. Vichiato MRM, Vichiato M, Castro MC, Dutra LF, Pasqual M, Marchiori-Junior W, Lima CDF, Salgado CC. Análises estomática e morfométrica de folhas de plantas diplóides e tetraplóides de Dendrobium nobile Lindl. Rev Ceres. 2006;53(310):541-548.

37. Vichiato MRM, Vichiato M, Pasqual M, Castro DM, Dutra LF. Indução e identificação de tetraploides em Dendrobium nobile Lindl. (Orchidaceae). Rev Ci Agron. 2007;38(4):385-390.

38. Vichiato MRM, Vichiato M, Pasqual M, Rodrigues FA, Castro DM. Morphological effects of induced polyploidy in Dendrobium nobile Lindl. (Orchidaceae). Crop Breed Appl Biotechnol. 2014;14(3):154159, doi:10.1590/1984-70332014v14n3a23.

39. Wannakrairoj S, Wondyifraw T. In vitro chromosome doubling in Korarima [Aframomum corrorima (Braun) P.C.M. Jansen] using colchicine and oryzalin. Kasetsart J Nat Sci. 2013; 47(5):684-694.

40. Xu L, Najeeb U, Naeem MS, Daud MK, Cao JS, Gongh J, Shen WQ, Zhou WJ. Induction of tetraploidy in Juncus effusus by colchicine. Biol Plantarum. 2010;54(4):659-663, doi:10.1007/s10535-010-0117-9

41. Yang X, Cao Z, An L, Wang Y, Fang X. In vitro tetraploid induction via colchicine treatment from diploid somatic embryos in grapevine (Vitis vinifera L.). Euphytica. 2006;152(2):217-224, doi:10.1007/s10681-006-9203-7.

42. Younis A, Ryu KB, Co VT, Hwang YJ, Jee SO, Kim MS, Kim CK, Lim KB. Analysis of chromosomes and nuclear DNA content in nine genotypes of Cymbidium. Flower Res J. 2013;21(4):158-161, doi:10.11623/frj.2013.21.4.31 